\title{
PELAKSANAAN K3 PADA PROYEK PEMBANGUNAN INTERCHANGE BOYOLALI
}

\author{
Herman Susila \\ Program Studi Teknik Sipil, Fakultas Teknik, Universitas Tunas Pembangunan Surakarta \\ Hermansusila73@gmail.com
}

\begin{abstract}
Abstrak
Pekerjaan konstruksi merupakan pekerjaan yang syarat dengan resiko kecelakaan kerja. Dari sumber-sumber literatur diperoleh data bahwa Kecelakaan kerja pada sektor konstruksi merupakan sektor tertinggi dalam kecelakaan kerja di Indonesia. Hal ini menimbulkan pertanyaan bagaimana pelaksanaan keselamatan kerja pada proyek konstruksi. Dalam Undang-Undang No.1 tahun 1970 tentang keselamatan kerja mengatur dengan jelas tentang kewajiban pimpinan tempat kerja dan pekerja dalam melaksanakan keselamatan kerja. Tujuan dalam penelitian ini adalah untuk mengetahui pelaksanaan keselamatan dan kesehatan kerja pada proyek Pembangunan Interchange Boyolali. Penelitian dilakkukan dengan metode deskriptif. Data diambil melalui pengamatan langsung di lapangan dan wawancara dengan questioner. Pengamatan dilakukan pada lokasi kerja, pekerjaan galian tanah, pekerjaan talud, pekerjaan tanah urug, pekerjaan pemadatan tanah dan pekerjaan beton. Hasil analisis data didapat 7 item tindakan K3 dari 10 item tindakan K3 dilokasi kerja sudah dilaksanakan. Tindakan k3 yang belum dilaksanakan adalah memberi barikade pada daerah berbahaya, memberri tanda yang jelas pada daerah berbahaya dan lokasi tidak rapih. Hasil analisi mean jawaban rensponden dalam hal penggunaan APD (Alat Pelindung Diri) sebesar 2,36. Hal ini menunjukkan bahwa pelaksanaan K3 pada proyek Pembangunan Interchange Boyolali adalah kurang.
\end{abstract}

Kata kunci: kecelakaan kerja, keselamatan kerja, K3, proyek konstruksi

\begin{abstract}
Construction projects are jobs that require the risk of accidents. From the literature source, it is obtained work accident data in the highest construction sector in Indonesia. This raises a question how the application of work safety in construction projects. In UU No.1 of 1970 concerning occupational safety, this regulation clearly regulates the obligations of leaders and workers in the workplace in implementing work safety. The purpose of this study was to determine the implementation of occupational safety and health in the Boyolali Interchange Development project. This research was conducted using descriptive methods. Data was taken through direct observation in the field and interviews with questionnaires. Observations were made at work sites, earthworks, burial work, landfill work, soil compaction work and concrete work. The results of data analysis showed that 7 items of OSH actions from 10 items of $\mathrm{K} 3$ actions at work sites had been carried out. K3 actions that have not been implemented are giving barricades to hazardous areas, giving clear signs to dangerous and untidy locations. The results of the analysis of the average response of respondents in terms of the use of PPE (Personal Protective Equipment) amounted to 2.36. This shows that the implementation of K3 in the Boyolali Interchange Development project is still lacking.
\end{abstract}

Keywords: workplace accidents, work safety, occupational safety and health, construction projects 


\section{PENDAHULUAN Latar Belakang}

Proses pembangunan konstruksi pada umumnya adalah kegiatan yang banyak mengandung unsur bahaya (Ervianto, 2002). Situasi dan kondisi lokasi proyek yang penuh dengan material, alat-alat konstruksi, pekerja konstruksi yang jumlahnya besar dan pekerjaan-pekerjaan yang membutuhkan tenaga dan fisik yang kuat, ini semua merupakan lingkungan kerja yang mengandung resiko kecelakaan kerja cukup besar. Dari hasil penelitian Endroyo (2010) kecelakaan kerja yang sering terjadi karena factor manusia (human error). Penelitian ini juga menunjukkan perilaku pekerja terhadap pelaksanaan Keselamatan dan kesehatan Kerja (K3) sangat kurang. Banyak sekali factorfaktor yang mempengaruhi perilaku pekerja terhadap K3, diantaranya adalah komitmen perusahaan dalam mengimplementasikan K3. Dengan masih banyaknya kecelakaan kerja pada pekerjaan konstruksi bisa berarti perusahaan konstruksi kurang maksimal dalam pengelolaan K3.

\section{Permasalahan}

Dalam Undang-Undang No.1 tahun 1970 tentang keselamatan kerja mengatur dengan jelas tentang kewajiban pimpinan tempat kerja dan pekerja dalam melaksanakan keselamatan kerja. Sesuai undangundang tersebut perusahaan jasa konstruksi juga harus melaksanakan keselamatan kerja. Namun kenyataan yang terjadi adalah kecelakaan kerja di sector konstruksi merupakan sector tertinggi dalam kecelakaan kerja di Indonesia. Perumusan masalah dalam penelitian ini adalah bagaimana implementasi pengelolaan K3 di perusahaan jasa konstruksi?

\section{Batasan masalah}

Penelitian ini dilaksanakan pada proyek Pembangunan Interchange
Boyolali.

\section{Tujuan Penelitian}

Penelitian ini bertujuan untuk mengetahui implementasi K3 proyek Pembangunan Interchange Boyolali.

\section{LANDASAN TEORI Keselamatan Kerja}

Keselamatan kerja adalah keselamatan yang berhubungan dengan mesin, alat kerja, bahan dan proses pengolahannya, landasan tempat kerja dan lingkungannya serta cara-cara melakukan pekerjaan (Triyanto, 2004). Keselamatan menurut OHSAS 18001-

1999 adalah bebas dari resiko buruk yang tidak dapat diterima. Bubshait dan Almohawis dalam Endroyo (2010) menyatakan bahwa keselamatan adalah penyelesaian proyek tanpa kecelakaan. Kesehatan kerja adalah suatu keadaan atau kondisi badan/tubuh yang terlindungi dari segala ancaman atau gangguan yang dikibatkan oleh pekerjaan yang dilaksanakan (Milen, 2016). Keselamatan kerja diatur dalam Undang-Undang Nomor 1 Tahun 1970. Undang-undang ini bersifat preventif, sehingga memberikan rasa aman dan dapat mempertinggi mutu kerja, peningkatan produksi dan produktifitas kerja.

\section{Kecelakaan Kerja}

Kecelakaan kerja adalah kejadian yang tidak diharapkan, tidak diramalkan, tidak direncanakan, tidak terduga serta tidak ada unsur kesengajaan yang wajar dari suatu kegiatan dan dapat mengakibatkan suatu luka atau kerusakan pada benda atau peralatan (Sudinarto 1995). Pengertian kecelakaan kerja menurut Hinz dalam Endroyo (2007) adalah kejadian yang tidak direncanakan, tidak terduga, tidak diharapkan serta tidak ada unsur kesengajaan.. kejadian tersebut biasanya bersifat fisik dan 
merugikan. Factor-faktor penyebab kecelakan kerja

secara umum adalah (Ervianto, 2004):

- Faktor pekerja

- Faktor metoda konstruksi

- Peralatan

- Manajemen

Terdapat beberapa teori kecelakaan kerja dalam konstruksi. Sebelum teori ini berkembangng, pemahaman tentang penyebab kecelakaan kerja adalah karena kesalahan tindakan yang dilakukan oleh pekerja. Setelah teori teori tentang kecelakaan kerja berkembang, maka penyebab kecelakaan kerja adalah pada pihak organisasi dan manajemen (Endroyo, 2006). Adapun teori-teori kecelakaan kerja yang ada sekarang adalah (Endroyo, 2007):

The Accident-Proneness Theory, teori ini dikemukakan oleh Vernon pada tahun 1918. Vernon menyatakan bahwa kecelakaan kerja dapat terjadi karena kepribadian pekerja (individu). Menurut teori ini kecelakaan kerja dapat terjadi pada seseorang yang mempunyai karakter yang dapat menebabkan kecelakaan kerja.

Goals-Freedom-Alertness Theory, teori ini dikemukakan oleh Kerr pada

tahun 1957. Teori ini menyatakan bahwa kecelakaan kerja terjadi karena perilaku kerja yang bermutu rendah dalam kondisi psikologis yang buruk.

The Chain of Events Theory, teori ini menyatakan bahwa kecelakaan kerja terjadi sebagai hasil kegiatan yang berantai. Semua peristiwa terhubungkan dalam deretan, dan masing-masing peristiea diikuti oleh peristiwa yang lainnya.

The Domino Theory, teori ini dikemukakan oleh Heinrich pada tahun 1930. Teori ini disemprnakan oleh Bird (1974) dan Adam (1976). Teori ini mengemukakan tentang model penyebab kecelakaan kerja, dimana suatu kecelakaan digambarkan salah satu dari lima factor dalam suatu urutan yang mengakibatkan suatu luka atau kerusakan. Perilaku tentang factorfaktor yang terlibat adalah serupa dengan robohnya kartu domino ketika diganggu. Jika satu kartu jatuh maka kartu yang lain akan jatuh juga. Dalam model ini Heinrich mengemukakan lima kartu domino, yaitu keluarga dan social lingkungan, kesalahan orang, tindakan tidak aman dan/atau resiko fisik atau mekanik, kecelakaan, dan luka-luka/kerugian.

The distraction Theory, dalam teori ini dinyatakan bahwa keselamatan

bersifat situasional. Teori ini dikembangkan untuk ditetapkan pada situasi dimana terdapat dua factor sebagai berikut: (1). Potensi/resiko bahaya (hazard) atau distraksi/pengacauan mental yang sudah dikenali . (2). Tugas pekerjaan/aktivitas yang telah dirumuskan dengan baik.

The Constrain Renponse Theory, dalam teory ini menyatakan bahwa kecelakaan adalah gejala alami. Semua pihak yang terlibat dalam konstruksi sejak tahap konsepsi sampai desain dan konstruksi dapat menghasilkan kondisi atau situasi yang dapat mengarah ke peningkatan resiko kecelakaan kerja.

\section{Manajemen Kesehatan dan keselamatan Kerja (K3)}

Sesuai dengan perkembangan teori penyebab kecelakaan kerja bahwa penyebab kecelakaan kerja adalah organisasi dan manajemen, maka dalam pelaksanaan konstruksi perlu adanya pengelolaan resiko kecelakaan kerja dengan membentuk organisasi yang terstruktur dan menjalankan k3 melalui system manajemen kesehatan dan keselaman kerja. System manajemen K3 adalah bagian dari 
sistem manajemen secara keseluruhan yang meliputi struktur organisasi,

perencanaan, tanggung jawab, pelaksanaan, prosedur, proses dan sumber daya yang dibutuhkan bagi pengembangan, penerapan, pencapaian, peng-kajian dan pemeliharaan kebijakan K3 dalam rangka pengendalian resiko yang berkaitan dengan kerja guna terciptanya tempat kerja yang aman, efisien dan produktif (Peraturan Menteri Pekerjaan Umum Nomor. 09 / PER / M / 2008)

Manfaat penerapan Sistem Manajemen Keselamatan dan Kesehatan Kerja (SMK3) bagi perusahaan menurut Tarwaka dalam Pangkey at.al (2012) adalah:

1. Pihak manajemen dapat mengetahui kelemahankelemahan unsur sistem operasional sebelum timbul gangguan operasional, kecelakaan, insiden dan kerugian-kerugian lainnya.

2. Dapat diketahui gambaran secara jelas dan lengkap tentang kinerja K3 di perusahaan.

3. Dapat meningkatkan pemenuhan terhadap peraturan perundangan bidang K3.

4. Dapat meningkatkan pengetahuan, ketram-pilan dan kesadaran tentang K3, khususnya bagi karyawan yang terlibat

dalam pelaksanaan audit.

5. Dapat meningkatkan produktivitas kerja

Alat Pelindung Diri (APD)

Alat Pelindung Diri (APD) adalah suatu alat yang mempunyai kemampuan untuk melindungi seseorang yang fungsinya mengisolasi sebagian atau seluruh tubuh dari potensi bahaya di tempat kerja (Suma'mur, 1981). APD memiliki jenis dan fungsi. Penggunaan APD disesuaikan dengan area kerja. Alat pelindung kepala, yaitu berfungsi untuk melindungi kepala dari benturan, terantuk, kejatuhan atau terpukul benda tajam atau benda keras yang melayang atau meluncur di udara, terpapar oleh radiasi panas, api, percikan bahan kimia, dan suhu yang ekstrim. Jenis alat pelindung kepala adalah helm pengaman (safety helmet), topi atau tudung kepala, penutup atau pengaman rambut, dan lain-lain. Alat pelindung mata dan muka, yaitu berfungsi untuk melindungi muka dari paparan bahan kimia berbahaya, percikan benda-benda kecil, panas, pancaran cahaya dan pukulan benda keras atau benda. Alat pelindung kaki, yaitu berfungsi untuk melindungi kaki dari menginjak bendabenda tajam seperti paku. Selain itu juga untuk melindungi kaki dari

ketatuhan benda dari atas. Jenis alat pelindung kaki adalah semua jenis sepatu boot. Alat pelindung tangan, yaitu berfungsi melindungi tangan dari benda-benda keras dan tajam. Jenis alat pelindung tangan adalah sarung tangan dari jenis katun, karet atau kulit, sarung tangan penahan panas. Alat pelindung telingan, yaitu berfungsi untuk melindungi telinga dari bunyi-bunyi yang ditimbulkan oleh mesin dengan volume suara yang cukup keras dan bising. Alat pelindung pernafasan, yaitu berfungsi untuk melindungi pernafasan agar terlindung dari material konstruksi yang berukuran kecil, seperti serbuk kayu sisa dari kegiatan memotong, mengamplas atau menyerut kayu.

\section{METODE PENELITIAN}

\section{A. Lokasi Penelitian}

Metode penelitian yang digunakan dalam penelitian ini adalah berikut :

1. Observasi/ pengamatan dilapangan 
- Mengadakan wawancara dan pengamatan langsung di lapangan

- Mengumpulkan data-data yang diperlukan

2. Melakukan studi kepustakaan Mempelajari tentang keselamatan dan kesehatan kerja berdasarkan studi literatur dan buku-buku acuan yang berkaitan dengan topik penelitian ini.

3. Analisis Data

Metode analisis data dilakukan dengan cara menyusun, membahas dan mengevaluasi data-data dan hasil wawancara/observasi mengenai penerapan $\mathrm{K} 3$ di lokasi proyek.

\section{HASIL DAN PEMBAHASAN \\ Pelaksanaan Proyek Pembangunan Interchange Boyolali}

PembangunanInterchange

Boyolali yang terletak di Desa Kragilan, Kecamatan Mojosongo, Kabupaten Boyolali bertujuan untuk meningkatkan pelayanan dan kenyamananpengguna jalan khususnyamasyarakat Boyolali dan wilayah sekitarnya. Pembangunan ini adalah pekerjaan pembangunan jalan baru dengan konstruksi LPA dan Rigid Pavement dengan sumber pendanaan dari APBD Kabupaten Boyolali Tahun Anggaran 2018.

PembangunanInterchange

Boyolali di Kabupaten Boyolali akan meningkatkan pelayanan dan kenyamanan pengguna jalan khususnyamasyarakat Boyolali juga bagi masyarakat Se-KabupatenBoyolali sekaligus dapat meningkatkan kualitas

jalan dan pendapatan pemerintah disektor transportasi.

\section{Pelaksanaan K3 Proyek Pembangunan Interchange Boyolali}

Pengukuran Penerapan Kesehatan dan Keselamatan Kerja dalam penelitian ini menggunakan skala likert sebagai berikut:

Sangat baik : 5

Baik : 4

Cukup : 3

Kurang : 2

Sangat kurang: 1

Untuk mendapatkan hasil pengukuran, maka dari nilai data ordinal dirubah menjadi data interval.

Interval

nilai maksimunm-nilai minimum jumlah kelas

Interval $=\frac{5-1}{5}=0,8$

Skala distribusi penilaian adalah sebagai berikut:

Nilai $1-1,8=$ pelaksanaan $\mathrm{K} 3$ sangat krang

Nilai $1,81-2,6=$ pelaksanaan $\mathrm{K} 3$ kurang

Nilai 2,61 - 3,4= pelaksanaan K3 cukup Nilai 3,41 - 4,2 = pelaksanaan K3 baik Nilai $5,21-5,0=$ pelaksanaan K3 sangat baik

Data diambil dengan observasi lapangan, wawancara dan questioner. Responden yang dipilih adalah mandor

atau kepala tukang. Lingkup pengamatan adalah lokasi proyek, pekerjaan galian tanah, pekerjaan talud, pekerjaan tanah urug, pekerjaan pemadatan tanah dan pekerjaan beton.

Table 1. Checklist keselamatan dan kesehatan kerja pada lokasi kerja

\begin{tabular}{|c|c|c|c|}
\hline No & Uraian & Ya & Tidak \\
\hline 1 & $\begin{array}{l}\text { Pekerja dapat mencapai tempat } \\
\text { kerja dengan aman }\end{array}$ & $\sqrt{ }$ & \\
\hline 2 & $\begin{array}{l}\text { Daerah berbahaya dilengkapi } \\
\text { dengan barikade }\end{array}$ & & $\sqrt{ }$ \\
\hline 3 & $\begin{array}{l}\text { Daerah berbahaya ditandai } \\
\text { dengan jelas }\end{array}$ & & $\sqrt{ }$ \\
\hline 4 & $\begin{array}{l}\text { Tempat kerja bebas dari barang- } \\
\text { barang berbahaya, tumpukan } \\
\text { material dan barang-barang } \\
\text { buangan }\end{array}$ & $\sqrt{ }$ & \\
\hline 5 & $\begin{array}{l}\text { Pengumpulan dan pemindahan } \\
\text { sisa material telah direncanakan } \\
\text { dengan matang }\end{array}$ & $\sqrt{ }$ & \\
\hline 6 & $\begin{array}{l}\text { Lokasi rapih dan bahan-bahan } \\
\text { tersimpan dengan aman }\end{array}$ & & $\sqrt{ }$ \\
\hline 7 & $\begin{array}{l}\text { Penerangan untuk pekerjaan } \\
\text { cukup }\end{array}$ & $\sqrt{ }$ & \\
\hline 8 & Tersedia kamar mandi yang & $\sqrt{ }$ & \\
\hline
\end{tabular}




\begin{tabular}{|l|l|l|l|}
\hline & cukup & & \\
\hline 9 & Tersedia air minum yang cukup & $\sqrt{ }$ & \\
\hline 10 & Tersedia obat-obatan P3K & $\sqrt{ }$ & \\
\hline
\end{tabular}

Dari table 1 diperoleh hasil bahwa kontraktor telah melaksanakan 7 item dari 10 item atau $70 \%$ pelaksanaan $\mathrm{k} 3$ di lokasi pekerjaan. Tindakan yang belum dilakukan adalah memberi barikade pada daerah berbahaya, memberri tanda yang jelas pada daerah berbahaya dan lokasi tidak rapih.

Tabel 2. Checklist peralatan dan hasil questionare keselamatan dan kesehatan kerja

\begin{tabular}{|c|c|c|c|c|}
\hline \multirow[t]{2}{*}{ No } & \multirow[t]{2}{*}{ Jenis Peerjaan } & \multicolumn{2}{|c|}{$\begin{array}{l}\text { Dipakai } \\
\text { Pekerja }\end{array}$} & \multirow[t]{2}{*}{ Tersedia } \\
\hline & & Ya & Tidak & \\
\hline $\mathbf{A}$ & $\begin{array}{ll}\text { Pek. } & \text { Galian } \\
\text { Tanah } & \\
\end{array}$ & & & \\
\hline 1 & $\begin{array}{l}\text { Pelindung } \\
\text { kepala }\end{array}$ & $\sqrt{ }$ & & Ada \\
\hline 2 & Pelindung mata & $\sqrt{ }$ & & Tidak \\
\hline 3 & Masker & $\sqrt{ }$ & & Ada \\
\hline 4 & Sarung tangan & $\sqrt{ }$ & & Ada \\
\hline 5 & Pelindung kaki & $\sqrt{ }$ & & Ada \\
\hline B & Pek. Talud & & & \\
\hline 1 & $\begin{array}{l}\text { Pelindung } \\
\text { kepala }\end{array}$ & $\sqrt{ }$ & & Ada \\
\hline 2 & Pelindung mata & $\sqrt{ }$ & & Tidak \\
\hline 3 & Masker & $\sqrt{ }$ & & Ada \\
\hline 4 & Sarung tangan & $\sqrt{ }$ & & Ada \\
\hline 5 & Pelindung kaki & $\sqrt{ }$ & & Ada \\
\hline $\mathbf{C}$ & $\begin{array}{ll}\text { Pek. } & \text { Tanah } \\
\text { Urug } & \\
\end{array}$ & & & \\
\hline 1 & $\begin{array}{l}\text { Pelindung } \\
\text { kepala }\end{array}$ & $\sqrt{ }$ & & Ada \\
\hline 2 & Pelindung mata & $\sqrt{ }$ & & Ada \\
\hline 3 & Masker & $\sqrt{ }$ & & Ada \\
\hline 4 & Sarung tangan & $\sqrt{ }$ & & Ada \\
\hline 5 & Pelindung kaki & $\sqrt{ }$ & & Ada \\
\hline D & $\begin{array}{l}\text { Pek. } \\
\text { Pemadatan }\end{array}$ & & & \\
\hline 1 & $\begin{array}{l}\text { Pelindung } \\
\text { kepala }\end{array}$ & $\sqrt{ }$ & & Ada \\
\hline 2 & Pelindung mata & $\sqrt{ }$ & & Ada \\
\hline 3 & masker & $\sqrt{ }$ & & Ada \\
\hline 4 & Sarung tangan & $\sqrt{ }$ & & Ada \\
\hline 5 & Pelindung kaki & $\sqrt{ }$ & & Ada \\
\hline $\mathbf{E}$ & $\begin{array}{l}\text { Pekerjaan } \\
\text { Beton }\end{array}$ & & & \\
\hline 1 & $\begin{array}{l}\text { Pelindung } \\
\text { kepala }\end{array}$ & $\sqrt{ }$ & & Ada \\
\hline 2 & Pelindung mata & $\sqrt{ }$ & & Ada \\
\hline 3 & masker & $\sqrt{ }$ & & Ada \\
\hline 4 & Sarung tangan & $\sqrt{ }$ & & Ada \\
\hline 5 & Pelindung kaki & $\sqrt{ }$ & & Ada \\
\hline
\end{tabular}

Tabel 3. Descriptive Statistics

\begin{tabular}{|l|r|r|r|r|r|}
\hline & $\mathrm{N}$ & Min & Max & Mean & $\begin{array}{l}\text { Std. } \\
\text { Deviatio } \\
\mathrm{n}\end{array}$ \\
\hline $\begin{array}{l}\text { Pelindung } \\
\text { Kepala } \\
\text { Pelindung } \\
\text { Mata }\end{array}$ & 5 & 4.00 & 4.00 & 4.0000 & .00000 \\
$\begin{array}{l}\text { Masker } \\
\text { SarungTan } \\
\text { gan }\end{array}$ & 5 & 1.00 & 1.00 & 1.0000 & .00000 \\
$\begin{array}{l}\text { Pelindung } \\
\text { Kaki }\end{array}$ & 5 & 4.00 & 4.00 & 4.0000 & .00000 \\
Total & 5 & 11.00 & 12.00 & 11.800 & .44721 \\
Valid N & 5 & & & 0 & .00000 \\
(listwise) & & & & & .44721 \\
\hline
\end{tabular}

Dari table 2 dan table 3 di peroleh hasil analisis penggunaan peralatan keselamatan kerja (APD) oleh pekerja. Alat pelindung kepala dengan nilai mean 4,0. Alat pelindung mata dengan nilai mean 1,0. Masker dengan nilai mean 1,0. Sarung tangan dengan nilai mean 1,8. Dan alat pelindung kaki dengan nilai mean 4,0. Secara total mean untuk penggunaan APD adalah $11,8: 5=2,36$. Dari skala distribusi penilaian bahwa nilai mean 2,36 termasuk dalam interval pelaksanaan K3 adalah kurang. Walaupun sudah dilakukan di lapangan namun dari hasil pengamatan yang mengguankan APD hanya sebagian kecil.

\section{KESIMPULAN \\ Kesimpulan}

1. kontraktor telah melaksanakan 7 item dari 10 item atau $70 \%$ pelaksanaan k3 di lokasi pekerjaan. Tindakan yang belum dilakukan adalah memberi barikade pada daerah berbahaya, memberri tanda yang jelas pada daerah berbahaya dan lokasi tidak rapih.

2. Untuk penggunaan peralatan keselamatan kerja (APD) oleh pekerja, secara total mean untuk penggunaan APD adalah 2,36. Dari skala distribusi penilaian bahwa nilai mean 2,36 termasuk 
dalam interval pelaksanaan $\mathrm{K} 3$ adalah kurang. Walaupun sudah dilakukan di lapangan namun dari hasil pengamatan yang mengguankan APD hanya sebagian kecil.

\section{DAFTAR PUSTAKA}

Endroyo. Bambang, 2006, Peranan Manajemen K3 Dalam Pencegahan Kecelakaan Kerja Konstruksi, Jurnal Teknik Sipil UNIKA Soegijapranata, Volume III, No. 1. Januari 2006, hal. 8-15, UNIKA, Semarang

Endroyo. Bambang dan Tugino, 2007, Analisis Faktor-Faktor Kecelakaan Kerja Konstruksi, Jurnal Teknik Sipil dan Perencanaan, Nomor 1 Volume 9-Januari 2007, hal 21-31, UNES, Semarang

Ervianto, Wulfram. 2002. Manajemen Proyek Konstruksi, Andi, Yogyakarta

Hidayat. Benny, et.al, 2016, Kecelakaan Kerja Proyek Konstruksi di Indonesia Tahun 2005-2015: Tinjauan Content Analysis Dari Artikel Berita, Prosiding, Konferensi Nasional Teknik Sipil 10, Universitas Atma Jaya, Yogyakarta

Pangkey, at.al, 2012, Penerapan Sistem Manajemen Keselamatan dan Kesehatan Kerja (SMK3) Pada Proyek Konstruksi di Indonesia, Jurnal Ilmiah Media Engineering, vol 2, No. 2, Juli 2012 ISSN 2087-9334 (100-113)

Rijanto. Boedi, 2010, Pedoman Praktis Keselamatan, Kesehatan Kerja dan Lingkungan (K3L) Industri Konstruksi. Mitra Wacana Media, Jakarta

Sihombing,at.al, 2004, Implementasi Keselamatan dan Kesehatan Kerja (K3) Pada Proyek di Kota Bitung (studi kasus Proyek Pembangunan Pabrik Minyak PT. MNS), Jurnal
Sipil Statik, volume 2, No. 3, Maret 2004.

Triyanto. Djoko, 2004, Hubungan Kerja di Perusahaan Jasa Konstruksi, Mandar Maju, Bandung 